\title{
MEB 2013, Regulation for Administrator Assignment and Relocation Based On the Opinions of Administrators
}

\author{
Soner DOĞAN**
}

\author{
Selçuk Beşir DEMIR ${ }^{* * *}$
}

Received: 28 July 2014

Accepted: 14 November 2014

\begin{abstract}
In this study; it is aimed to determine the opinions of the institution managers concerning the Regulation for Administrator Assignment and Relocation dated February 28, 2013, the scoring criteria in the regulation and the disturbances experienced in the application process of the regulation. The study is carried out in accordance with the phenomenological pattern through qualitative research methods. The participants were determined with the criterion sampling method which is one of the purposeful sampling methods. The study group of the research is composed of the eight managers serving in a province. In the study, a semi-structured interview form was used as data collection tool. In the interpretation process of the interviews, the inductive descriptive analysis, the content analysis and the constant comparison technique were used. Three main themes have come out regarding the result of the data analysis process of assigning the administrators, the combining of the different types of institutions and the application of the forced relocation.
\end{abstract}

Keywords: regulation for administrator assignment and replacement, selection of school administrator, process of assignment school administrator

\section{Extended Abstract}

Purpose and Significance: The appointment criteria for education managers in Turkey are modified frequently with regulations. The Ministry of National Education has published 7 regulations (regulations for the administrator assignment prepared in 2004, 2006, 2007, 2008 and 2009, 2011 and 2013) and many circulars since 2004 according to the views of various trade unions, teachers, institution managers and the academic studies on this issue. Researchers need to determine whether the Regulation for Administrator Assignment and Relocation entered into force in 2013 provides a solution for the issues causing debates and problems in the old regulations or not. Furthermore, it must be determined how the scoring criteria and the content of the new regulation are perceived by the related persons of the issue. Besides, the requirement such as the determination of the incorrect or incomplete aspects of the new regulation and its positive or negative reflections on the administrator assigning process were the basis in making this research.

With reference to the theoretical framework above, in this study; it is aimed to determine the opinions of the institution managers concerning the Regulation for Administrator Assignment and Relocation dated February 28, 2013, the scoring criteria in the regulation and the disturbances experienced in the application process of the

\footnotetext{
** Corresponding Author: Assist. Professor, Cumhuriyet University, Sivas, Türkiye, snr312@gmail.com

*** Assist. Professor , Cumhuriyet University, Sivas, Türkiye, sbesdem@hotmail.com

**** Teacher, MEB, Sivas, Türkiye, malipınar82@hotmail.com
} 
regulation. By examining the current status concerning the administrator assignment, this study becomes very important since it is aimed to produce solution for the problems experienced in the appointment of the education managers in the future.

Method: The study is carried out in accordance with the phenomenological pattern through qualitative research methods. The participants were determined with the criterion sampling method which is one of the purposeful sampling methods. The study group of the research is composed of eight managers serving in the province of (alias). In the study, a semi-structured interview form was used as data collection tool. In the interpretation process of the interviews, the inductive descriptive analysis, the content analysis and the constant comparison technique were used.

Results: At the end of the data analysis of the research; three main themes have come out. These are: 1 . The evaluations regarding the Executive Recruitment, 2. With the new regulation, the evaluations regarding the combining of the different institutions as only one type of institution, 3. The evaluations regarding the forced relocation (rotation).

In the research, the evaluations regarding the process of executive recruitment have focused on four categories. These categories are the evaluations as of oral and written examinations, the evaluations regarding the relocation by the governors' offices, the choosing of the executives among those who have a five year experience of teaching and the presence of the unionists in the province evaluation committees. The results reached at the end of this research are: all the participants have agreed that the written exam is essential in the process of relocation while the oral exam may not be just; all the participants except for the participant-2 have agreed that the choosing one among three determined among the teachers in the institution by the governor is not applicable and all the participants except for the participant- 4 have stated that the direct recruitment of the administers among the teachers who have a five-year experience of teaching and got a high grade in the exam is not suitable and all the participants except for the participant- 6 have stated that the presence of a unionist in the province evaluation committees is just and democratically correct.

While the participant-1, the participant- 2 and the participant-8 have supported the idea of combining different types of institutions in a bid to terminate an unjust application, the participant-3 and the participant- 4 have objected the application considering that this application may give way to unjust behaviors and not properly functioning of the institutions due to the lack of experience. While the participant- 6 and participant-7 have defended that the types of the institutions should not be touched but the criteria governing these types should be re-considered, the participant-5 has put forward that the types of the institutions is not a new phenomenon for the principals but added that it must definitely be applied for the principal assistants.

The participant- 5 and the participant- 6 stated that the forced rotation of the principals who have worked in an institution for a five year term can be detrimental for the family unity of the principals and the principals can compensate the deficiencies of the schools 
in a period of at least eight years, and supported the new regulation which stipulate a longer period of time after which the principals can be subjected to the forced relocation. All the participants except for the participant- 5 and the participant- 6 have stated that the time for the rotation is quite long and during this period the principals may lose their motivation and start to behave as if the school is his/her own property, may be less efficient and this will be an unjust application for other principals.

Discussion and Conclusions: Since their job descriptions are different, the participants have objected the idea that the teachers with a five-year experience of teaching can be principals. In this regard, the findings of Akyüz (2007) regarding the working duration and experience, Serin (2007) and Korkmaz (2005) regarding experience and success, Babaoğlan (2008), Dönmez and Güneş (2001) and Koçak (2009) regarding the relationship between professional seniority and burnout have all supported the relevant ideas of the participants. The opinions of the participants regarding the forced relocation coincide with those of Kurtulmuş, Günda and Ardiç (2012) who states that the administrators support the forced relocation and with those of Tonbul and Sağıroğlu (2012) who state that the forced relocation has both positive and negative sides. 


\section{Yönetici görüşlerine göre MEB 2013 Yılı Yönetici Atama ve Yer Değiştirme Yönetmeliği}

Soner DOĞAN**

\author{
Selçuk Beşir DEMIR ${ }^{* * *}$
}

Makale Gönderme Tarihi: 28 Temmuz 2014

Makale Kabul Tarihi: 14 Kasım 2014

ÖZET: Bu çalışmada; 28 Şubat 2013 tarihli Yönetici Atama ve Yer Değiştirme Yönetmeliği’ne, yönetmelikte yer alan puanlama ölçütlerine ve yönetmeliğin uygulanışı sürecinde yaşanan aksaklıklara ilişkin kurum yöneticilerinin görüşlerinin belirlenmesi amaçlanmıştır. Çalışma, nitel araştırma yöntemleriyle, olgubilim desenine uygun olarak yürütülmüştür. Araştırmada, katılımcılar amaçlı örnekleme yöntemlerinden ölçüt örnekleme yöntemi ile belirlenmiştir. Araştırmanın çalışma grubu, bir ilde görev yapan 8 yöneticiden oluşmaktadır. Araştırmada, veri toplama aracı olarak; yarı yapılandırılmış görüşme formu kullanılmıştır. Görüşme verilerinin yorumlanması sürecinde endüktif (inductive) betimsel analiz, içerik analizi ve sürekli karşılaştırma tekniği (constant comparison) kullanılmıştır. Verilerin analizi sonucunda yönetici atama sürecine, farklı kurum tiplerinin birleştirilmesine ve zorunlu yer değiştirme uygulamasına ilişkin üç ana tema ortaya çıkmıştır.

Anahtar sözcükler: yönetici atama ve yer değiştirme yönetmeliği, okul yöneticisi seçme, okul yöneticisi atama süreci

\section{Giriş}

Türkiye'de eğitim yöneticiliğine atanma ölçütleri s1k s1k yönetmeliklerle değiştirilmektedir. Eğitim örgütlerine yönetici olarak atanacaklarda 1990 yılından önce, eğitim-öğretim sınıfından olmak ve üç yıl başarılı öğretmenlik yapmak gibi çok genel ölçütler aranmasına karşın daha sonraları bazı standartlar oluşturulmaya başlanmıştır (Aslanargun, 2011). 1999 tarihi itibariyle ilk defa yönetici atamalarına seçme sınavı sistemi getirilmiştir. Yapılan yönetici seçme sınavında 70 veya daha fazla puan alan adaylar başarılı sayılarak bu adaylara beş yıl geçerli olan yöneticilik sertifikası verilmiş ve norm kadrosu boş bulunan okul yöneticilikleri için başvuru yapma hakkı verilmiştir (Günay, 2004).

2003 tarihinde yayınlanan MEB Yönetici Atama ve Görevde Yükselme Yönetmeliği'nin EK-1 Değerlendirme Formu'nda toplam puanı en fazla olandan başlamak üzere ilan edilen boş kadro sayısının iki katı personel belirlenerek görevde yükselme eğitimine alınmış, 75 saat eğitimin tamamına katılanlar görevde yükselme sınavına girmeye hak kazanmıştır. Sınava girecek adaylara Bakanlık Ölçme Değerlendirme Merkezi (BÖDM) tarafindan yapılan sınavda en az 70 puan almaları da ön koşul olarak konmuştur (MEB, 2003).

2004 yılında çıkarılan yönetmelikte okul ve kurum müdürlükleri dört yönetim kademesine ayrılmış, birinci basamak olan müdür yardımcılığı için seçme sınavı şartı getirilmiş; müdür başyardımcılığı, C, B ve A tipi müdürlükler için belirli yıl müdür yardımcılığı yapmış olma ön şartına bağlı olarak mülakat sınavında başarılı olma ölçütü belirlenmiştir (Günay, 2004; MEB, 2004). 2006 yılında yapılan değişikliklerle, 2004 yılında çıkarılan yönetmelik yeniden düzenlenmiş, önceki yönetmelikte sadece müdür

\footnotetext{
** Sorumlu Yazar: Yardımcı doçent doktor, Cumhuriyet Üniversitesi, Sivas, Türkiye, snr312@gmail.com

*** Yardımcı doçent doktor, Cumhuriyet Üniversitesi, Sivas, Türkiye, sbesdem@hotmail.com

***** Öğretmen, MEB, Sivas, Türkiye, malipınar82@hotmail.com.
} 
yardımcılığı için seçme sınavı yapılması ön görülmüş iken, bu yönetmelikle müdürlük için de "Düzey Belirleme Sınavı" uygulaması getirilmiştir ve bu sınavlardan 100 üzerinden 70 alanların başarılı sayılarak sözlü sınava alınacakları belirtilmiştir (MEB, 2006).

2007 yılında çıkarılan ve idare mahkemesince yürürlügü durdurulan yönetmeliğe göre eğitim kurumları yöneticiliklerine ilçe ve il milli eğitim müdürlüklerinin görüşleri doğrultusunda atamaya yetkili amirlerce atama yapılması öngörülmüştür. Müdür yardımcısı olarak atanabilmek için öğretmenlikte adaylığı kaldırılmış olmak yeterli iken okul müdürlügü için kurum tipine göre bir, iki veya üç yıl müdür yardımcılığı yapmış olanlar arasında ilçe milli eğitim müdürünün teklifi ve il müdürünün uygun görüşü üzerine atamaya yetkili amir tarafından atama yapılacağı hükme bağlanmıştır. Sınav sisteminin kaldırıldığı bu yönetmeliğe göre milli eğitim üst düzey yöneticilerin görüş ve önerileri üzerine okul ve kurumlara yönetici atanması uygun görülmüştür. $\mathrm{Bu}$ yönetmelik, üzerinden birkaç ay geçtikten sonra idare mahkemesince iptal edilmiştir (MEB, 2007).

2008 yılında çıkarılan yönetmeliğe göre yönetim görevlerine atanma ölçütü olarak Yönetici Değerlendirme Formu üzerinden yapılacak puanlama esas alınmış, daha önceki yönetmeliklerde öngörülen sınav sistemi veya üst düzey yöneticilerinin uygun görüşü gibi uygulamalardan vazgeçilmiştir. Öğretmenlikte ve müdür yardımcılığında geçen süreler, ödül ve hizmet içi eğitim belgeleri gibi evrak üzerinden elde edilen puanlamaların değerlendirme komisyonlarınca onaylanması sonucunda eğitim kurumlarına yönetici atanması öngörülmüş; ancak kısa süre içerisinde bu yönetmelik de idare mahkemesince iptal edilmiştir (MEB, 2008).

2009 yılında hazırlanan yönetmelik, şekil yönünden geçmişte çıkarılan yönetmeliklerin bir sentezi görünümünü vermektedir. 2004 y1lında sadece müdür yardımcılığı için öngörülen seçme sınavı bu yönetmelikle müdürlük için de zorunlu hale getirilirken, yer değiştirme söz konusu olduğunda yönetici değerlendirme formu üzerinden yapılacak puanlamanın esas alınacağı hükme bağlanmıştır. Yönetmeliğin ilk halinde sınavlardan 60 puan alanlar başarılı kabul edilmiştir (MEB, 2009).

2011 yılında yayımlanan yönetmelik ile geçmiş yıllarda yayımlanan yönetmeliklerde eleştirilen bazı hususlar değiştirilmiştir. Yeni değişikliklerle birlikte atanılmak istenilen eğitim kurumlarına, Talim Terbiye Kurulu Kararlarına göre alanları itibari ile öğretmen olarak atanabilecek alan öğretmeni olma koşulu getirilmiştir. Ayrıca asker öğretmen olanlar, yurt dışında öğretmen olarak görevli bulunanlar, 657 sayılı yasa ve 4688 sayılı yasa kapsamında aylıksız izinli olanlara istemeleri halinde başvuru hakkı tanınmıştır. Yine, eğitim kurumu müdürleri aralıksız asaleten 5 yıl, eğitim kurumlarının müdür başyardımcısı ve müdür yardımcıları ise aralıksız asaleten 8 yıl çalışma süresini tamamlayanlar zorunlu yer değiştirmeye (rotasyon) tabi tutulacağı belirtilmiştir (MEB, 2011).

2013 y1lında yürürlüğe giren yönetmeliğe göre ise 2011 yılındaki yönetmelikte bulunan kurum tipleri (A, B, C) kaldırılmış, bu yönetmeliğe göre tüm eğitim kurumlarının tek tip eğitim kurumu olarak değerlendirilmesi esas alınmıştır. Yine aynı 
şekilde 2011 yılındaki yönetmelikte adayların başvuracakları eğitim kurumlarına alanı itibarı ile öğretmen olarak atanabilme şartı aranırken, yeni yönetmelikte "alanı itibarı ile

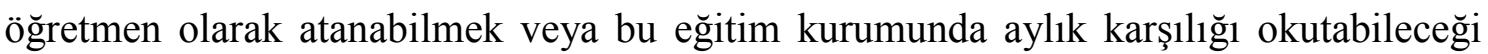
ders bulunmak" şartı getirilerek 2009 yılında yürürlüğe konulan ve daha sonra yürürlükten kaldırılan hüküm tekrar geri getirilmiştir. 2011 yılındaki yönetmeliğe göre müdürlük sınavına girmek için yöneticilik yapmış olmak şartı aranırken, yeni yönetmelikte "beş yıl öğretmen kadrosunda görev yapmış olmak" şartı getirilmiştir. Ayrıca yeni yönetmelikte müdür ve müdür yardımcılığına atamalarda sözlü sınav getirilmiştir. Buna göre; yazılı sınav puanına göre, puanı en yüksek olan altı aday sözlü sınava çağrılacaktır. Yazılı sınav puanının yüzde 50'si, sözlü sınav puanının yüzde 30'u ve Yönetici Değerlendirme Formu'na göre hesaplanan puanın yüzde 20'si alınarak her eğitim kurumu için valiliğe sunulmak üzere toplam puanı en yüksek olan üç aday belirlenecek, valilik bu üç adaydan birisinin yönetici olarak atamasını yapacaktır. İlk defa 2011 yılındaki yönetmelikle uygulamaya konulan okul idarecilerine rotasyon uygulaması yeni yönetmelikte müdür başyardımcıları ve müdür yardımları için 8 yıl olarak uygulamaya devam ederken, okul müdürlerin zorunlu yer değiştirme süresi 5 yıldan 8 yıla çıkarılmıştır (MEB, 2013).

2004 yılından günümüze değin yönetmeliklerin içeriği ve puanlama ölçütleri konunun tarafları arasında çeşitli eleştirilere tabi tutulmuştur. Milli Eğitim Bakanlığı tarafından çeşitli sendikaların, öğretmenlerin, kurum yöneticilerinin görüşleri ve bu hususta yapılan akademik çalışmalar doğrultusunda 2004 yılından bugüne kadar konuyla ilgili problemleri ortadan kaldırmak adına 7 yönetmelik (2004, 2006, 2007, 2008 ve 2009, 2011 ve 2013 y1llarında hazırlanan yönetici atama yönetmelikleri) ve birçok genelge yayınlanmıştır. 2013 yılından önce yayınlanan Yönetici Atama ve Yer Değiştirme Yönetmelikleri; Bakioğlu ve Özcan (2001), Cemaloğlu (2005), Günay (2004), Korkmaz (2005), Serin (2007), Silah (2001), Özmen ve Kömürlü (2010), Taş ve Önder, (2010), Turan ve Şişman (2000), Yeloğlu (2008) tarafından yapılan çalışmalarda içerik ve puanlama ölçütleri bakımından çeşitli eleştirilere tabi tutulmuştur. Tüm bu eleştiriler ve tartışmalar sonucunda Milli Eğitim Bakanlığı tarafından 2013 tarihinde geçmiş genelge ve yönetmelikler üzerinde revizyonlar yapılarak 2013 tarihli yeni bir Yönetici Atama ve Yer Değiştirme Yönetmeliği yayınlamıştır.

2013 yılında yürürlüğe giren, Yönetici Atama ve Yer Değiştirme Yönetmeliği'nin eski yönetmeliklerde tartışmalara ve problemlere neden olan hususlara çözüm sağlayıp sağlamadığına yönelik araştırmalara ihtiyaç duyulmaktadır. Ayrıca yeni yönetmeliğin içeriğinin ve puanlama ölçütlerinin konunun ilgilileri tarafından nasıl algılandığının tespit edilmelidir. Bunların yanı sıra yeni yönetmeliğin hatalı veya eksik yönlerinin ve yönetici atama süreci üzerinde olumlu veya olumsuz yansımalarının belirlenmesi gibi gereklilikler bu araştırmanın yapılmasında temel teşkil etmiştir.

Yukarıda yer verilen kuramsal çerçeveden hareketle, bu çalışmada; 2013 tarihli Millî Eğitim Bakanlığı Eğitim Kurumları Yöneticileri Atama ve Yer Değiştirme Yönetmeliği'ne, yönetmelikte yer alan puanlama ölçütlerine ve yönetmeliğin uygulanış1 sürecinde yaşanan aksaklıklara ilişkin kurum yöneticilerinin görüşlerini belirlemek 
amaç edinilmiştir. Yönetici atama ve yer değiştirme sürecine ilişkin mevcut durumu inceleyerek, gelecekte eğitim kurumları yöneticilerinin atanmasında yaşanan sorunlara çözüm üretmek amacı güdüldüğünden bu çalışma önem arz etmektedir.

Bu kapsamda araştırmanın problem cümlesi:

28 Şubat 2013 tarihli resmi gazetede yayımlanan Yönetici Atama ve Yer Değiştirme Yönetmeliği'ne, yönetmelikte yer alan puanlama ölçütlerine ve yönetmeliğin uygulanışı sürecinde yaşanan aksaklıklara ilişkin kurum yöneticilerinin görüşleri nelerdir?

\section{Yöntem}

Araştırmada, konunun derinlemesine irdelenebilmesi için nitel bir yaklaşım tercih edilmiştir. Nitel araştırma "araştırmacıların araştırarak konu ya da konuları doğal ortamda inceledikleri, araştıran insanların getirmiş oldukları anlamlar açısından olguyu anlamlaştırma ve yorumlama çabası içerisinde oldukları bir araştırma yöntemi” olarak tanımlanmaktadır (Denzin ve Lincoln, 1998; akt: Ekiz, 2003: 27).

\section{Araştırmanın Deseni}

Araştırmada, Milli Eğitim Bakanlığı'na bağlı kurumlarda görev yapan yöneticilerin yeni Yönetici Atama ve Yer Değiştirme Yönetmeliği’nin içeriğine ilişkin görüşlerinin derinlemesine incelenmesi amaç edinildiği için araştırma konusunun doğasına uygun olan olgubilim/fenomenoloji deseni kullanılmıştır. Olgubilim araştırmalarında bir durum veya olayın tüm boyutları olduğu gibi derinlemesine incelenmesi amaçlanır. Aynı zamanda bireyin yaşantılarını algı görüş ve düşüncelerini ortaya çıkarmaya yöneliktir (Yıldırım ve Şimşek, 2011).

\section{Araştırmanın Çalışma Grubu}

Araştırmada, katılımcılar amaçlı örnekleme yöntemlerinden ölçüt örnekleme dikkate alınarak seçilmiştir. Amaçlı örnekleme yöntemleri tam anlamıyla nitel araştırma süreci içinde ortaya çıkmıştır. Amaçlı örnekleme zengin bilgiye sahip olduğu düşünülen durumların derinlemesine çalışılmasına olanak vermektedir (Yıldırım ve Şimşek, 2011). Patton (2002) amaçlı olarak seçilen örneklemin seçiminde hedef, çalışılan konu ile ilgili olarak daha fazla bilgi sunacak kişileri seçmenin temel amaç olduğunu ve sayı konusunda esnek olunabileceğini belirtmektedir. Ölçüt örnekleme yöntemindeki temel anlayış ise önceden belirlenmiş bir dizi ölçütü karşılayan bütün durumların çalışılmasıdır. Burada sözü edilen ölçüt veya ölçütler araştırmacı tarafından oluşturulabilir ya da daha önceden hazırlanan bir ölçüt listesi kullanılabilir (Yıldırım ve Şimşek, 2011). Katılımcılar belirlenmeden önce araştırmacı tarafından bir ölçüt listesi oluşturulmuştur. Katımcıların belirlenmesinde ölçüt olarak, Milli Eğitim Bakanlığı'na bağlı kurumlarda yönetici olarak görev yapmak kriteri dikkate alınmıştır. Ayrıca çalışma grubu belirlenirken müdür ve müdür yardımcısı sayılarının eşit olması amaçlanmıştır. Katılımcılar belirlenirken görüşme yapmayı kabul etme ve katılmaya istekli olma durumu da göz önünde bulundurulmuştur. Araştırma etiği çerçevesinde 
katılımcıların isimleri kullanılmamış, katılımcılara M1'den M8'e kadar kodlar verilmiştir.

\section{Veri Toplama Aracı}

Araştırmada, Milli Eğitim Bakanlığı'na bağlı kurumlarda görev yapan yöneticilerin;yeni Yönetici Atama ve Yer Değiştirme Yönetmeliği’nin içeriğine, yönetmelikte yer alan puanlama ölçütlerine, yönetici atama ve yer değiştirme sürecine ilişkin görüşlerini belirlemek amacıyla açık uçlu sorulardan oluşan Yarı Yapılandırılmış Mülakat (Görüşme) Formu kullanılmıştır. Görüşme, bireylerin deneyimlerine, görüşlerine, tutumlarına ilişkin bilgi edinmede kullanılan veri toplama aracıdır. Görüşme, doğal bir iletişim ve bilgi toplama yolu olduğundan anlaşılmayan konularda açıklama, soru sorma ve tamamlama yapmaya olanak sağlamasının yanı sıra araştırma yapılan konuda daha çok ve ayrıntılı bilgilere ulaşılabilmesine de zemin hazırlar (Silverman, 2005).

Katılımcıların görüşme esnasında verdikleri cevapların altında yatan nedenleri derinlemesine irdeleyebilmek ve sürece bağlı olarak katılımcılara yeni sorular yöneltebilmek amacıyla, çalışmada; Yarı Yapılandırılmış Görüşme Formu tercih edilmiştir. Görüşme soruları hazırlanmadan önce 09.08.2011 tarihli 28020 sayılı Resmi Gazetede yayımlanan Yönetici Atama ve Yer Değiştirme Yönetmeliği ayrıntılı olarak incelenmiş yönetmelik çerçevesinde belirlenen alt başlıklar ile alan yazında yer alan çalışmalar ayrıntılı olarak karşılaştırılmıştır. Yapılan karşılaştırmalar sonucunda hazırlanan taslak görüşme formu soruları, eğitim bilimleri alanında uzman bir öğretim üyesi tarafından araştırmanın amacı doğrultusunda değerlendirilmiştir. Ayrıca nitel araştırma yöntemleri konusunda uzman bir öğretim üyesi tarafından, açık uçlu sorular ayrıntılı bir incelemeye tabi tutulmuştur. İlgili uzmanlardan gelen geribildirimler doğrultusunda görüşme soruları yeniden şekillendirilmiştir. Daha sonra iki Türkçe Öğretmeni tarafından ifade bozukluğu olan veya anlaşılması güç olabilecek sorular yeniden değerlendirilmiştir.

Uzman görüşleri doğrultusunda yeniden şekillendirilen görüşme formu için pilot uygulama, araştırmanın katılımcılar arasında yer almayan bir okul müdür ile gerçekleştirilmiştir. Yapılan pilot uygulama sürecinde elde edilen geribildirimler doğrultusunda görüşme formu yeniden şekillendirilmiştir. Tüm bu uygulamalarla; inandırıcı, tutarlı, teyit edilebilir ve aktarılabilir bir görüşme formu hazırlanmaya çalışılmıştır. Elde edilen bilgilerden yararlanılarak görüşme formuna son hali verilmiş, görüşme soruları 1. Yöneticilerin atama sürecini nasıl değerlendiriyorsunuz?, 2. Yeni yönetmelikle birlikte farklı kurum tiplerinin tek tip kurum tipine dönüştürülmesi konusundaki düşünceleriniz nelerdir? 3. Zorunlu yer değiştirme (rotasyon) uygulamas1 hakkında ne düşünüyorsunuz? şeklinde katılımcılara yöneltilmiştir. Çalışmada tüm katılımcılara yukarıda belirtilen sorular sorulmuştur. Ancak konunun ve verilen cevapların derinlemesine irdelenebilmesi amaciyla, verilen cevaplar referans alınarak farklı sorular da (follow-up questions) katılımcılara yöneltilmiştir. 
Araştırmaya ilişkin veriler araştırma kapsamındaki katılımcıların okullarında görüşme yapılarak toplanmıştır. Görüşmeler 2013 yılının Mart ayı boyunca sürmüştür. Araştırma kapsamında 250 dakikalık görüşme yapılmıştır. Katılımcılara araştırmanın amacından söz edilerek, kişisel bilgilerinin gizli tutulacağına dair ayrıntılı açıklamalar yapılmıştır. Ayrıca katılımcılara, araştırma boyunca elde edilen verilerin araştırmanın amacı dışında kullanılmayacağı taahhüt edilmiştir. Görüşmeler esnasında verilerin kaybını önlemek için ses kayıt cihazı katılımcıların onayı ile kullanılmıştır. Görüşmelerden sonra ses kayıtları yazılı metne dönüştürülmüş ve bu metinler katılımcılara tek tek sunulmuş, kendi görüşleri olduğuna ilişkin onay alınmıştır.

\section{Verilerin Analizi}

Görüşmelerin dökümü. Araştırma sürecinde tüm görüşmeler ses kayıt cihazıyla kayıt altına alınmıştır. Araştırma kapsamında 240 dakikalık görüşme yapılmış, ses kayıtları herhangi bir elemeye tabi tutulmadan, ham veri olarak Microsoft Word yazı işleme programıyla bilgisayar ortamına aktarılmıştır.

Verilerin kodlanması. Veriler kodlanmadan önce iki araştırmacı tarafından verilerin dökümü olan transkriptler satır satır okunmuştur. Katılımcılar tarafından çalışma amacı hakkında doğrudan açıkça beyan edilmiş veya dolaylı olarak ima edilmiş görüşler manipüle edilmeden betimlemek için Patton (2002) tarafından ifade edilen satır-satır analiz (line by line analysis) yaklaşımı kullanılmıştır. Bir kelime, kelime öbekleri veya bir cümle veri analizi için bir birim teşkil etmiştir.

Araştırmanın amacı çerçevesinde önemli olan boyutlar saptanmıştır ve her bir boyutun ne anlam ifade ettiği belirlenmeye çalışılmıştır. Kodlamalarda katılımcılar tarafından ifade edilen kelime ve kavramlar mümkün olduğu kadar kodlamada kullanılmıştır. Ancak katılımcıların kullandıkları kelime ve kavramların kodlama sürecinde yetersiz kaldığında durumu/düşünceyi en iyi ifade edebilecek başka kavramlar kod olarak araştırmacılar tarafından belirlenmiştir.

Yorumlama teknikleri. Görüşme verilerinin yorumlanması sürecinde endüktif (inductive) betimsel analiz, içerik analizi ve sürekli karşılaştırma tekniği (constant comparison) kullanılmıştır (Marshall ve Rossman, 1999; Miles ve Huberman 1994).

Betimsel analiz süreci. tematik çerçevenin oluşturulması, tematik çerçeveye göre verilerin işlenmesi, bulguların tanımlanması ve bulguların yorumlanması olmak üzere dört ana aşamadan oluşmuştur. Betimsel analizde, görüşülen bireylerin görüşlerini çarpıcı bir şekilde yansıtmak için sık sık doğrudan alıntılara yer verilir (Yıldırım ve Şimşek, 2011).

İçerik analizi ise toplanan verilerin derinlemesine analiz edilmesini gerektirir ve önceden belirgin olmayan temaların ve boyutların ortaya çıkarılmasına olanak tanır (Çepni, 2005; Yıldırım ve Şimşek, 2011). Bu bağlamda katılımcılardan elde edilen veriler incelenmiş ve ayni kavramları çağrıştıran kodlar ortak kategoriler altında birleştirilmiştir. Son aşamada verilerden çıkan temalardan anlam bütünlüğü sağlanıp, 
yorumlama yoluna gidilmiştir. Araştırmacılar, tematik kodlama sürecinde ortaya çıkan her tema altında yer alan verilerin bütününü kapsayıp kapsamadığını belirlemek için, alan uzmanlarının görüşlerine sıklıkla başvurmuş ve geri bildirimler doğrultusunda tematik kodlama sürecinde yapılan eksiklikler ve yanlışlıklar düzeltilmiştir.

$\mathrm{Bu}$ çalışmada içerik analizinin yanı sıra sürekli karşılaştırma veri analizi metodu da kullanılmıştır. Sürekli karşılaştırmalı veri analizi, incelenen verilerin tümevarım kategori şeklinde kodlanması ve aynı zamanda incelenmekte olan verileri sürekli olarak karşılaştırma işlemini kapsamaktadır (Ekiz, 2003). Bu bağlamda, araştırma verileri analiz edilirken katılımcıların vermiş olduğu cevaplar içerisinde sürekli tekrarlanan olgu ve olaylar belirlenmiş, sürekli birbirleriyle karşılaştırılmış ve bu olgu ve olaylardan yola çıkılarak tümevarım yöntemiyle kategorilere ve temalara ulaşılmaya çalışılmıştır.

\section{Araştırmada Geçerlik ve Güvenirlik}

Nitel araştırmalarda geçerlik ve güvenirlik kavramları yerine inandırıcılık, aktarılabilirlik, tutarlılık ve teyit edilebilirlik kavramlarının kullanılması daha doğru bir yaklaşım olacaktır. Geçerlik ve güvenirlik kavramları nicel araştırmalara özgü kavramlar niteliğinde olup, nitel araştırmaların temel ilkeleri ve temel paradigması ile çelişmektedir (Mills, 2003). Bu nedenle çalışmada geçerlik ve güvenirlik kavramlarının yerine inandırıcılık, aktarılabilirlik, tutarlılık ve onaylanabilirlik kavramları kullanılması uygun görülmüştür.

İnandırıcılık (İç geçerlik). Araştırmanın iç geçerliğini (inandırıcılığını) artırmak amacıyla görüşme formu geliştirilirken ilgili alanyazın incelenerek, konu ile ilgili bir kavramsal bir çerçeve oluşturulmuştur. Görüşme sonrası kişilerin söyledikleri yazılı hale dönüştürülerek, katılımcılardan elde edilen yazılı metinleri kontrol etmeleri ve kendi görüşlerinin olup olmadığı teyit ettirilmiştir

Çalışmada içerik analizi aşamasında elde edilen temalar, ilgili kavramları kapsayacak kadar geniş ve ilgisiz kavramları dışarıda bırakacak kadar dar kapsamda belirlenmeye özen gösterilmiştir. Bu temalar ve temaları oluşturan kategorileri kendi aralarındaki ilişkisi ile her bir temanın diğerleriyle ilişkisi kontrol edilerek elde edilen bulgular arasında bütünlük sağlanmaya çalışılmıştır. Araştırmanın uygulama sürecindeki tüm görüşmeler ses kayıt cihazıyla kayıt altına alınmıştır. Araştırmacılar, araştırmanın tüm aşamalarında mümkün olduğunca nesnel olmaya dikkat etmiştir. Araştırma sürecinde elde edilen tüm veriler iki araştırmacı birbirinden bağımsız olarak kodlama yapmış ve tüm kodlamalar arasında genel anlamda görüş birliği sağlanmıştır.

Aktarılabilirlik (Dış geçerlik). Araştırmanın aktarılabilirliğini artırmak için araştırma sürecinin her aşaması ayrıntılı bir şekilde okuyucuya sunulmuştur. Nitel çalışmalarda dış geçerlilik genel olarak karşılaştırılabilirlik ve dönüştürülebilirlik üzerinde yoğunlaşır.Bu bağlamda araştırmacılar araştırma raporunu ayrıntılı olarak yazmaya özen göstermiş ve bulgular bölümünde ayrıntılı betimlemeler yapmaya çalışmıştır. Araştırmanın raporlaştırma aşamasında derin ve ayrıntılı betimlemeler yapmasının temel amaci; araştırma sürecinin tüm öğelerini okuyucunun gözünde 
canlandırma isteğidir. $\mathrm{Bu}$ nedenle araştırmacılar, bulgular ve yorumlar bölümünde doğrudan alıntılara yer vermiştir. $\mathrm{Bu}$ doğrultuda araştırmacılar toplanan betimsel verilerin benzer bağlamlardaki çalışma gruplarına transfer edilebileceği, başka araştırma sonuçlarıyla karşılaştırılabileceği kanaatindedir.

Araştırmacılara göre; bu araştırmada elde edilen sonuçların, araştırmayı okuyanlar arasında aynı veya benzer şekilde anlaşılması gerekmektedir. Bu bağlamda, araştırma sürecinin ve araştırma ortamının okuyucuların zihinlerinde canlanabilmesine olanak sağlamak için, araştırmacılar tarafından araştırıma ile ilgili aktarımlar sade ve anlaşılır bir üslupla özetlenmiştir.

Tutarlılık (İç güvenirlik). Araştırmanın iç güvenirliğini (tutarlığını) artırmak için çalışmada elde edilen bulguların tamamı yorum ve genelleme yapılmadan doğrudan okuyucuya sunulmuştur. Araştırma sürecinde elde edilen tüm veriler, araştırmacının kendisi dışında, başka bir araştırmacı tarafından değerlendirip, ayrı ayrı kodlanmış ve tüm kodlamalar arasında genel anlamda görüş birliği sağlanmıştır. İki araştırmacının birbirinden bağımsız olarak kullandıkları kodların tutarlığ "Görüş Birliği”" ya da "Görüş Ayrılığı" şeklinde işaretlemeler yapılarak belirlenmiştir. Araştırmada tüm kodlamalar güvenilirlik hesaplaması için; Miles ve Huberman'ın (1994) önerdiği güvenirlik formülü [Güvenirlik= Görüş Birliği / (Görüş Birliğgi + Görüş Ayrılığı)] kullanılmıştır.

Güvenirlik hesaplarının \%70'in üzerinde çıkması, araştırma için güvenilir kabul edilmektedir (Miles ve Huberman, 1994:64). Hesaplama sonucunda en düşük güvenirliğe sahip; birinci soru (\% 86) olurken; en yüksek güvenirliğe sahip soru ise üçüncü soru (\% 95) olarak belirlenmiştir.

Teyit edilebilirlik (Dış güvenirlik). Araştırmanın dış güvenirliğini (teyit edilebilirliğini) sağlamak için, süreç içinde elde edilen ham veriler ve kodlamalar ilgililerin inceleyebilmelerine imkân sunmak için araştırmacılar tarafından saklanmaktadir.

\section{Bulgular}

Verilerin analizi sonucu; 1. Yöneticilerin Atama sürecine ilişkin değerlendirmeler, 2. Yeni yönetmelikle farklı kurum tiplerinin tek tip kurum tipine dönüştürülmesine ilişkin değerlendirmeler 3. Zorunlu yer değiştirme (rotasyon) uygulamasına ilişkin değerlendirmeler olmak üzere üç ana tema ortaya çıkmıştır.

\section{Yöneticilerin Atama Sürecine İlişkin Değerlendirmeleri}

Araştırmada, yöneticilerin atama sürecine ilişkin değerlendirmeleri temasının altında 4 kategoriye ulaşılmıştır. Her kategori birbirleriyle yakından ilişkili ve bağımlıdır. Bu kategoriler şu şekilde ifade edilebilir:

a) Sözlü ve yazılı sınav uygulamasına ilişkin değerlendirmeler

b) Valiliklerce atama yapılmasına ilişkin değerlendirmeler

c) Müdürlerin 5 yıl öğretmenlik yapmış olanlar arasından seçilmesine ilişkin değerlendirmeler 
d) Sendikaların il değerlendirme kurulunda bulunmasına ilişkin değerlendirmeler

Sözlü ve yazılı sınav uygulamasına ilişkin değerlendirmeler. Katılımcıların tamamı atanma sürecinde yapılan yazılı sınavın gerekli olduğu konusunda ortak görüş bildirmişlerdir. Sınavın içeriği tartışılsa da yazılı sınavın objektif ve adil bir değerlendirme imkânı sağladığını belirten katılımcılar, yönetici olmak için başvuru yapanların ihtiyaç olan yönetici normuna göre çok fazla olduğunu dolayısıyla bir eleme sisteminin gerektiğini ifade etmişlerdir. Katılımc1- 3 "eğer yazılı sinav olmasaydı yönetici atamalarının çivisi çıkardı" söylemiyle yazılı sınava duyulan ihtiyaca vurgu yapmiştır.

$\mathrm{Bu}$ yıl tekrar uygulamaya konulan sözlü sınav yöntemine ise katılımcı-4 ve katılımc1-7 hariç diğer katılımcılar şiddetle karşı çıkmışlardır. Değerlendirme sistemi içerisinde insan unsurunun olmasının öznel yaklaşımlara neden olabileceğini belirten katılımcılar, sözlü sınav komisyonunda yer alan kişilerin yoğun bir baskı altında kalacaklarını ve bu baskıdan dolayı sağlıklı karar veremeyeceklerini dile getirmişlerdir.

Komisyonda yer alan üyelere güvenmek adına elinde herhangi bir dayanak olmadığını belirten katılımcı-1 “tamamen vicdanlarına kalmış" söylemiyle yaşadığı çaresizliği betimlemiştir. Katılımc1-5 ise komisyon üyelerinin yönetici seçme konusunda ne düzeyde yeterliliğe sahip olduğunun soru işareti olarak her zaman zihinlerde kalacağını ifade ederken "komisyon üyelerinin yönetici seçme yeterliliklerini belirleyecek bir komisyona daha ihtiyaç var” söylemiyle yaşanan çelişkiye dikkat çekmiştir.

Sözlü sınav konusunda daha iyimser bir tablo ortaya koyan katılımc1-4 ve katılımc1-7 ise her ne kadar objektifliği tartışma konusu olsa da yöneticilerin sözlü sınava alınmasını gerekli bir uygulama olarak değerlendirmektedirler. Yöneticiliğin sadece bürokratik bir süreç olmadığını yöneticilerin aynı zaman da temsil yeteneğinin de olması gerektiğini belirten katılımc1-4 ve katılımc1-7 yöneticilerin temsil yeteneğinin ancak sözlü bir değerlendirme ile sınanabileceğini ifade etmişlerdir. Bu konuda kat1lımc1- 7 "Arkadaşımız yönetici olmak istiyor. Deli gibi çalışıp bütün yazılı konularını ezberliyor ve yazllı sinavdan yüksek bir not alıyor ve ataniyor. Okulda görevine başlıyor. Ama bir bakıyorsunuz iletişim yeteneği sıfır, öğretmenlerle empati kuramıyor, bürokratik mekanizmayı dahi çözemiyor. Ataması yapıldı̆̆ için geri dönüş imkanı da yok. O zaman insana sormazlar mı bu kadar öğrencinin, ögretmenin, velinin suçu nedir?” söylemiyle sözlü sınavın gerekliliğini savunmuştur. Katılımc1-4 ise iyi bir yöneticinin insan ilişkilerinde başarılı, ikna kabiliyeti olan ve sempati duyulan bir lider olası gerektiğine vurgu yaparak yönetici atamalarında adaylarla mutlaka görüşme yapılması gerektiğini dile getirmiştir.

Valiliklerce atama yapılmasına ilişkin değerlendirmeler. $\mathrm{Bu}$ yıl yeni bir uygulama ile okul için belirlenen 3 adaydan birisinin vali tarafından atanması durumu yönetmelikte en çok tartışılan ölçütlerden birisi olmuştur. Bu konuda katılımc1- 2 hariç tüm katılımcılar olumsuz görüş bildirmişlerdir. Katılımcılara göre valilerin yöneticileri 
yeterince tanımadıkları için objektif bir değerlendirme yapmaları mümkün değildir. $\mathrm{Bu}$ nedenle ortaya çıkacak sıkıntıları Katılımc1-3 "Valilik de adaylar arasından istediğini yönetici olarak atıyor. "Peki buradaki ölçü nedir? Neye göre seçiyorlar? O da belli değil, o da bir soru işareti oluşturuyor insanda" Bu uygulamayı ben kendim onaylamıyorum. Yani düşünün arkadaşlarımız yüksek sınav puanı aldılar fakat bu sınav puanı ile atanamadılar. O kadar emekleri boşa gitti. Madem sınav yapıldı, en azından o sınava dayalı atama yapılması lazım gelirdi" şeklinde betimlerken valiliğin atama sistemi içerisinde olmaması gerektiğine vurgu yapmıştır. Katılımcı bir ise başka bir endişesini "valilerimizde, kaymakamlarımızda çoğu kez siyasi baskılar altında kalıp görevini layıkıla yapamıyorlar" ifadesiyle aktarırken Katılımc1-4 ise "Bu torpil kokan ve uygulaması mümkün olmayan bir yönetmenliktir" söylemiyle yönetmeliğe olan güvensizliğini dile getirmiştir. Bu konuda tek olumlu görüş bildiren Katılımc1-2 valiliğin atama sisteminde yer almasının gerekliliğini "Valilik en azından soruşturuyor" cümlesiyle özetlemiştir.

Müdürlerin 5 yıl öğretmenlik yapmış olanlar arasından seçilmesine ilişkin değerlendirmeler. Katılımcı-4 dışında diğer tüm katılımcılar 5 yıl öğretmenlik yapmış birinin sınavdan aldığı başarılı not ile doğrudan okul müdürü olarak atanmasına şiddetle karşı çıkmışlardır. Katılımcılar özellikle öğretmen ve okul müdürünün görev tanımlarının çok farklı olduğuna, belli bir müdür yardımcılığı tecrübesi olmadan okul müdürü olmanın beraberinde büyük sıkıntılar getireceğine vurgu yapmışlardır.

İdarecilik deneyiminin oluşabilmesi için okul müdürü olma süresinin 8-10 y1l aralığına çekilmesi gerektiğini ifade eden katılımc1-1 bu düşüncesini “Ínsanın kişiliğinin oturması, sosyal ilişkilerinin gelişmesi için bir olgunluğa ihtiyaç var, diye düşünüyorum. Sadece sinavda sorularl bilip not alıp yüzlerce öğrencinin ve binlerce ögrencinin sorumluluğunu omuzlarda taşımak, sınavda ki başarlyla ölçülemez. Yani bir idarecilik tecrübesi ve kıdem tecrübesinin olması lazım" söylemiyle desteklerken, bu konuda katılımc1-2 "bir müdür daha önce en azından bir 3 yıl müdür yardımcılı̆̆ yapsın ki biraz tecrübe edinsin” katılımc1-4 “Müdür olmak için önce müdür yardımcısı olmak lazım. Şimdi mantıken öğretmenlik başkadır, idarecilik başkadır. Müdür olmak için bir idarecilik tecrübesi gerekiyor" katılımc1-5 "Müdürlerin müdür yardımcılık kadrosunda olanlar arasından seçilip atanması daha uygun, daha makul olduğu düşüncesindeyim. Yani tecrübe olmadan direkt koltuğa oturmanın veya direkt müdür olmanın çok da yerinde bir karar olmadığı düşüncesindeyim” katılımcı-6 "Sadece kuru bir sinavla okul kurum müdürü olmak gerçekten zor. Çünkü insan müdür yardımcisıyken deneyim kazanıyor" ve katılımc1-8 "Direkt öğretmenlikten müdürlüğe geçiş şuandaki mevcut müdür yardımcılı̆̆ görevini yürüten kişilere de bence bir haksızlıktır" şeklinde benzer açıklamalarda bulunmuşlardır.

Öğretmen iken doğrudan okul müdürlüğüne geçişin şu anda görev yapan okul müdür yardımcılarına büyük bir haksızlık olduğunu savunan Katılımcı-8 uygulamanın yanlışlığına değinirken, yüksek bir puan alarak okul müdürü olan bir öğretmenin yaşayacağı sorunları katılımc1-7 "şimdi düşünün 5 yıllık ögrretmenlik tecrübesi olan biri diyelim ki idarecilik sınavında 100 puan aldı. X lisesi bir okulda mümkün değil 
müdürlük yapamaz. Bir kere müdür birinin belli bir süre idarecilik yapmış olması gerekiyor. Bunun e-okuludur, personel işleridir, öğrenci işleridir. Ya müdür dediğin bir kere bütün okulun işlerine hakimiyeti olacak ki daha sonra müdürlük yapabilsin. Müdürlük ile ögretmenliği ayrı tutmak lazım burada” ifadeleriyle dile getirmiştir. Ayrıca Katılımcı-7 köy okullarında sınırlı sayıda öğrencisi bulunan okullarda müdür vekilliği yapan kişilerin ilçe ve il merkezlerinde bulunan büyük okullara okul müdürü olarak atanmasına da karşı çıkmıştır.

\section{Sendikaların il değerlendirme kurulunda bulunmamasına ilişkin değerlendirmeler. İl değerlendirme komisyonunda sendika temsilcisinin} bulunmamasının daha objektif kararlar alınmasını sağlayacağını ifade eden katılımcı-5 ve sendika temsilcisi olsa da olmasa da il değerlendirme kurulunun var olmasının sakıncalı olduğunu ve kaldırılması gerektiğini belirten katılımcı-6 dışında diğer tüm katılımcılar sendika üyelerinin il değerlendirme kurulunda bulunmasını hakkaniyet ve demokratik bir tutum olarak gerekli gördüklerini ifade etmişlerdir. Bu konuda katılımc18 "Çok vahim bir durum bu. Yani sivil toplum kuruluşların böyle bir komisyonda bulunmaması biraz manidar bence. Bir yerlere birilerini getirmek için sanki bir şeylerin önü açılmak isteniyor" söylemiyle yapılan uygulamanın getireceği sonuçlara vurgu yapmiştır.

İl değerlendirme komisyonunda sendika temsilcisinin bulunmamasını çok antidemokratik bir uygulama olarak betimleyen katılımc1-1 "Tüm sendika yetkililerinin bu komisyonlarda veya ülkenin her alandaki komisyonlarda bulunmasl; daha demokratik, daha çağdaş, daha medenice bir tutum olurdu. Bence ayrım yapılmaksızın her 3 sendikanın da temsilcisinin olması gerekir" söyleminde bulunurken konuyla ilgili olarak katılımc1-2 "En fazla üyeye sahip olan iki sendikanın katılması lazım”, katılımc13 “Bence bu sayı 7 ise 9'a çıkarıp o bölgede en çok üyesi bulunan 2 sendikanın birer üye göndermesi daha uygun olur”, katılımc1-7 ise "Bence sadece tek sendika değil de gerekirse farkl sendikalardan da temsilcilerin de olmast daha objektif olacaktı" söylemlerinde bulunmuşlardır.

Komisyonun kaldırılması gerektiğini savunan katılımc1-6 bu isteğini "Komisyonda kim olduğu o kadar önemli değil. Sendikadan olmuş, milli ĕgitimden olmuş veya tarafsız insanların oluşturduğu komisyon olmuş, sonuçta ne olursa olsun bir komisyon varsa bunun içinde bir haksızlık mutlaka oluyor" söylemine dayandırırken il değerlendirme komisyonunda sendika temsilcilerinin bulunmasının objektifliğe zarar vereceğini iddia eden katılımc1-5 "Ama oraya seçilecek o 7 üyenin de ne kadar objektif olacă̆ yine akıllara şüpheler getiriyor" tespitiyle de aslında katılımc1-6'nın söylemlerine destek verdiği söylenebilir.

Yeni Yönetmelikle Farklı Kurum Tiplerinin Tek Tip Kurum Tipine Dönüştürülmesine İlişkin Değerlendirmeler

Katılımc1-1, katılımc1-2 ve kat1lımc1-8 farklı kurum tiplerinin tek tip kurum tipine dönüştürülmesine var olan bir haksızlığın giderildiği düşüncesi ile destek verirken, katılımc1-3 ve katılımc1-4 bu uygulamanın torpil yapılmasına neden olacağı ve 
tecrübe eksikliği nedeniyle büyük okulların iyi yönetilemeyeceği düşüncesi ile karş1 çıkmışlardır. Katılımcı-6 ve katılımc1-7 kurum tiplerinin kalması ancak kurum tiplerini belirleyen kriterlerin yeniden düzenlenmesi gerektiğini savunurken katılımc1-5 farklı bir bakış açısı ile kurum tiplerinin müdür yardımcıları için farklılık oluşturmadığını ancak müdürler için mutlaka uygulanması gerektiğine vurgu yapmıştır.

Kurum tiplerinin farklı olmasının mantıklı bir uygulama olmadığını ifade eden katılımc1-1 bu durumun eğitimcilerin başka eğitim kurumlarına giderken $\mathrm{A}, \mathrm{B}, \mathrm{C}$ diye sınıflandırılıp orada görev alamamasının kişilik haklarına aykırı olduğunu belirtirken katılımc1-1'i destekler nitelikte katılımcı-2 farklı kurum tiplerinde farklı çalışma sürelerinin isteniyor olmasının eşitlik ilkeleri ile bağdaşmadığını ve bu durumun çeşitli sorunlara yol açtı̆̆1, katılımc1-8 ise "Neticede köyde yöneticilik yapanla şehirde yöneticilik yapan aynı işleri yapıyorlar. Kurum tiplerinin farklı olması öğrenci sayısı ile ilgiliydi, derslik sayısı ile ilgiliydi. Neticede yöneticinin yaptı̆̆ görevi farklı kılan bir durum yoktu” söylemlerinde bulunmuşlardır.

Kurum tiplerinin tek bir çatı altında toplanmasının torpil uygulamalarını da beraberinde getireceğini savunan katılımcı-3 bu yönetmelik maddesi ile eskiden hizmet süresine bağlı olarak daha büyük okullarda çalışma olanağı olan müdürlerin bundan sonra haksızlığa uğrayarak hak ettikleri okullarda görev alamayacaklarını dile getirmiştir. Aynı şekilde bu yönetmelik maddesine karşı çıkan katılımcı-4 ise karşı çıkma nedenini müdürlerin sahip olması gereken birikime ve tecrübeye bağlamıştır. Bu konudaki itirazını katılımc1-4 "Büyük okulda çalışmakla asıl küçük okulda çalışmak arasında fark var. Çünkü ögrenci sayısı fazla, öğretmen sayısı fazla, girdisi çıktısı fazla; dolayısıla büyük okullarda çalışmak için biraz daha tecrübe gerekir. Yani önce C kurumunda bir tecrübe edinir, sonra B kurumunda, en sonunda A kurumunda çalışırsa daha mantıklı olur. Yani bütün okulları aynı düzeyde görmek yanlıştır” söylemiyle açıklamıştır.

Okul tiplerinin var olması gerektiğini ifade eden Katılımc1-6 bu görüşünü okul tipi kriterlerinin değişmesi gerekliliğine bağlamıştır. Var olan kurum tipi kriterleri nedeniyle bir köy okulu ya da kenar mahalle okulunun hiçbir zaman A tipi bir okul olamayacağını belirten Katılımcı-6 bu durumun ise okullarda birtakım sorunlara neden olacağını dile getirmiştir. Katılımcı-6 gibi Katılımc1- 7'de kurum tiplerinin kriterlerine ve kurum tiplerinin var olmasının gerekliliğine "Örneğin bizim okul X Lisesi 19002000 tane ögrencimiz var 60 tane ögrretmenimiz var mesela. Okulumuz B tipi bir okul. Bu tiplerin neye göre yapıldı̆̆ önemli bence. Yoksa tiplerin olması mantıklı bence. En azından tecrübesiz bir idareci önce C tipi bir okulda başlar, ögretmen ve ögrenci saylsı az olur, daha sonra bir tip yükselir. Bir iki yıl çalışır B tipine geçer. Belli bir standartlara göre yapılırsa tipler mantıklıdır, yoksa tek tip olmasına ben şahsen karşıyım." Söylemiyle açıklık getirmeye çalışmıştır.

Diğer katılımcılardan faklı bir bakış açısıyla katılımcı-5 konuyla ilgili düşüncelerini "Daha önceki yönetmelikte hizmet süresi esas alınarak bir üst kuruma atama oluyordu. Bu çok şart mıdır dersen, yani müdür yardımcılı̆̆ında şart değil ama müdürlük için şart. Müdür yardımcılarında öğrenci işleri disiplin işleri olduğu için 
kurum tipleri hani çok da önemli değil diye düşünüyorum. Ama müdürlük farklı olduğu için büyük okullarda tecrübe kazanması açısında eski yönetmelik daha uygun diye düşünüyorum." cümleleriyle betimlerken müdür ve müdür yardımcılarının durumuna ilişsin tespitlerde bulunmuştur.

\section{Yöneticilerin Zorunlu Yer Değiştirmeye (Rotasyon) Tabi Tutulmasına İlişkin Değerlendirmeler}

Beş yıl gibi kısa bir süre sonunda müdürlerin rotasyona uğramalarının onların aile düzenine zarar vereceğini ve okul müdürlerinin 8 yılda ancak okulun eksikliklerini tamamlayabileceğini ifade eden katılımc1-5 ve katılımc1-6 yeni yönetmelikle gelen ve süresi uzatılan rotasyon uygulamasının bu şekliyle uygun olduğunu savunmuşlardır. Katılımcı-5 ve katılımcı-6 dışında kalan diğer katılımcılar ise 8 yılın rotasyon için uzun bir zaman olduğunu, bu süre zarfinda müdürlerin performans düşüklüğü yaşayabileceklerini, pasif duruma düşebileceklerini, okulu sahiplenmeye başlayacaklarını, verimlerinin düşebileceğini ve diğer müdürlere haksızlık olabileceğini ifade etmişlerdir.

Eski yönetmeliğin bu yönetmelikten daha uygun maddeler taşıdığını belirten katılımc1-5 il ve ilçe müdürleri için 5 yılın uygun olduğunu ancak yaşadığı alanda düzenini kurmuş, aile olarak yerleşmiş ve ev almış müdürlerin 5 y1l da bir düzenlerinin bozulmasının beraberinde bir çok sorunlar getireceğini ifade ederken katılımc1-5 8 yılda bir rotasyon uygulamasına "Bir öğretmen ya da bir idareci 8 yıl bir okulda kaldı̆̆ zaman; o okulun bütün eksikliklerini görüp o eksiklikleri tamamlama şansina sahiptir. Fakat diyelim ki; siz 5 yılda, 4 yılda ya da 3 yılda rotasyona tabi tutarsanı; o insan o okula alışana kadar ya da tam alışıyorken; onu alıp başka bir yere vermeniz mantıklı değil” cümleleriyle karşı çıkmıştır.

Rotasyon süresinin 8 yıla çıkarılmasıyla müdürlerin okulu sahiplenmeye başlayacağını ifade eden katılımc1-5, bu süre zarfında okul müdürlerinin okulu kendi çiftlikleri gibi görmeye başlayacaklarını, katılımc1-1 müdürlerin idealist olsalar bile 8 yılda mutlaka performans kaybına uğrayacaklarını, katılımc1-3 ise müdürlerin ilk yıllarda verimli olmalarına rağmen yıllar geçtikçe verimlerini kaybettiklerini belirtmiştir. Katılımc1-7 bu konudaki düşüncelerini "Rotasyon için 8 yll olmasındansa 4-5 yıl olması daha ideal olurdu bence. Adam vardır güllük gülistanlık bir okula düşüyor yani orda 4-5 yıl çalışıp gitmektense 8 yıl orda kalacaktır. Öbür taraftan da mesela biri de bizim okul gibi yoğun bir okul, çok kötü bir okula düşecek 8 yll boyunca okulun kahrını çekecek. Bence 4-5 yıl olsa daha sağlıklı olurdu.” şeklinde paylaşarak oluşabilecek bir haksızlığa işaret etmiştir. Müdür ve müdür yardımcıları için rotasyona gerek olmadığını savunan katılımcı-8 ise konuya bakış açısını "Neticede bir okulda sorumlu olan amir, okul müdürüdür. Müdür yardımcılarının yönetim üzerinde müdürün isteği dışında bir etkisi yoktur. O yüzden müdür yardımcıların müdür başyardımcıların rotasyonunu olumlu bir çalışma olarak görmüyorum. "şeklinde özetlemiştir. 


\section{Sonuç ve Tartışma}

Araştırma bulgularına göre Katılımcı-4 dışında diğer tüm katılımcılar 5 yıl öğretmenlik yapmış birinin sınavdan aldığı başarılı not ile doğrudan okul müdürü olarak atanmasına şiddetle karşı çıkmışlardır. Katılımcılar özellikle öğretmen ve okul müdürünün görev tanımlarının çok farklı olduğuna, belli bir müdür yardımcılığ tecrübesi olmadan okul müdürü olmanın beraberinde büyük sıkıntılar getireceğine vurgu yapmışlardır. Katılımcıların özellikle hizmet süresi ve tecrübe üzerinde durması Akyüz'ün (2007) hizmet süresi ile tecrübe arasında ilişki olduğuna dair elde ettiği bulguları destekler niteliktedir. Bu bağlamda katılımcıların hizmet süresi ile yöneticilik başarısı arasında ilişki kurduğu söylenebilir. Literatürde benzer şekilde yer alan Serin (2007) ve Korkmaz'ın (2005) tecrübe ile başarı arasında doğrudan ilişki olduğuna dair paylaştıkları bulgular katılımcıların görüşleri ile paralellik göstermektedir. Ayrıca hizmet süresine ilişkin olarak Babaoğlan (2008), Dönmez ve Güneş (2001) ve Koçak (2009) tarafından yapılan çalışmalarda mesleki kıdeme bağlı olarak yöneticilerin tükenmişlik düzeylerinin arttığına bu nedenle iş doyumları ve dinamizmlerini kaybettiklerine ilişkin sonuçlara ulaşılmıştır. Bu sonuçlarda katılımcıların 5 yıllık öğretmenlik görevinden sonra sinavla okul müdürü olunması konusunda taşıdıkları endişelerin bazı kavramlar üzerinden bilimsel olarak literatürde yer aldığını göstermektedir.

Beş yıl gibi kısa bir süre sonunda müdürlerin rotasyona uğramalarının onların aile düzenine zarar vereceğini ve okul müdürlerinin 8 yılda ancak okulun eksikliklerini tamamlayabileceğini ifade eden katılımc1-5 ve katılımc1-6 yeni yönetmelikle gelen ve süresi uzatılan rotasyon uygulamasının bu şekliyle uygun olduğunu savunmuşlardır. Katılımcı-5 ve katılımcı-6 dışında kalan diğer katılımcılar ise 8 yılın rotasyon için uzun bir zaman olduğunu, bu süre zarfinda müdürlerin performans düşüklüğü yaşayabileceklerini, pasif duruma düşebileceklerini, okulu sahiplenmeye başlayacaklarını, verimlerinin düşebileceğini ve diğer müdürlere haksızlık olabileceğini ifade etmişlerdir. Bu konuya ilişkin olarak Kurtulmuş, Günda ve Ardıç'ın (2012), zorunlu yer değiştirmelerin yöneticiler tarafından desteklendiği bulgusuna ulaşmaları katılımcıların çoğunluğu tarafından belirtilen görüşlerle örtüşmektedir. Ancak Tonbul ve Sağıroğlu'nun (2012) yöneticilerde zorunlu yer değiştirme uygulamasının olumlu ve olumsuz yönleri olduğuna dair paylaştıkları araştırma sonuçları da katılımc1-5 ve katılımc1-6 nın beş yıl gibi kısa bir süre sonunda müdürlerin rotasyona uğramalarının onların aile düzenine zarar vereceği ve okul müdürlerinin 8 yılda ancak okulun eksikliklerini tamamlayabileceği yönündeki görüşlerini destekler niteliktedir.

Katılımcılar atama sistemini değerlendirirken genel olarak; yazılı sınavı objektif bulduklarını ve desteklediklerini, sözlü sınava öznel değerlendirmeye neden olacağından dolayı karşı çıktıklarını ve valiliğin yönetici atama sisteminde bulunmasının adil olmayacağına dair görüş bildirmişlerdir. Her ne kadar içeriği tartışılsa da yazılı sınavın tüm taraflar için en güvenilir uygulama olduğunu belirten katılımcılar sözlü sınav ile birlikte yazılı sınavın öneminin kalmadığını dolayısıyla sınavdan çok yüksek puan almış bir adayın dahi atanma garantisinin olmadığına vurgu yapmışlardır. 
Yeni uygulamanın valilere yönetici seçme modeli getirmesini valiliklerin siyasi baskı altında kalacağı ve valiliğin yöneticileri yeterince tanıma fırsatı bulamayacağ 1 şeklinde değerlendiren katılımcılar valiliğin bu atama sisteminde yer almaması konusunda katılımc1-2 dışında ortak görüş bildirmişlerdir. Bu görüşlerden yola çıkılarak bir önceki yönetmeliğin 2013 yılında yayınlanan yönetmeliğe göre daha tutarlı olduğu söylenebilir. $\mathrm{Bu}$ bağlamda sözlü sınav yerine yöneticilere gösterdikleri performansa göre verilen ödüllerin ağırlığının arttırılması önerilebilir. Çünkü Günay (2004) ve Silah (2001) yönetici ve personelin bilimsel, sosyal, kültürel v.b. faaliyetlerine yöneltmenin ve var olan başarıların takdir edilmesinin yönetici atama sürecinde kullanılması gereken ölçütler arasında yer aldığını ifade etmişlerdir. Ancak bu noktada da Özmen ve Kömürlü’nün (2010) öğretmenlerin ödüllendirilmesine ilişkin objektif ölçütlerin olmadığına dair görüşleri tereddüt oluşturmaktadır. Katılımcılar tarafından şiddetle karşı çıkılan sözlü sınav yerine hali hazırda yönetmelikte yer alan ve yönetici atamalarında etkili olan lisansüstü eğitimin ağırlığının arttırılması da düşünülebilir. Bu konuda Arıkan (2007), Cemaloğlu (2005) ve Yeloğlu (2008), Graczyk (1991), Ishida (1997) yapılan lisansüstü eğitimin okul yönetimi üzerinde olumlu sonuçlar doğurduğu sonucuna ulaşılmıştır.

İl değerlendirme komisyonunda sendika temsilcisinin bulunmamasının daha objektif kararlar alınmasını sağlayacağını ifade eden katılımcı-5 ve sendika temsilcisi olsa da olmasa da il değerlendirme kurulunun var olmasının sakıncalı olduğunu ve kaldırılması gerektiğini belirten katılımcı-6 dışında diğer tüm katılımcılar sendika üyelerinin il değerlendirme kurulunda bulunmasını hakkaniyet ve demokratik bir tutum olarak gerekli gördüklerini ifade etmişlerdir.

Katılımc1-1, katılımc1-2 ve katılımc1-8 farklı kurum tiplerinin tek tip kurum tipine dönüştürülmesine var olan bir haksızlığın giderildiği düşüncesi ile destek verirken, katılımc1-3 ve katılımc1-4 bu uygulamanın torpil yapılmasına neden olacağı ve tecrübe eksikliği nedeniyle büyük okulların iyi yönetilemeyeceği düşüncesi ile karş1 çıkmışlardır. Katılımcı-6 ve katılımcı-7 kurum tiplerinin kalması ancak kurum tiplerini belirleyen kriterlerin yeniden düzenlenmesi gerektiğini savunurken katılımc1-5 farklı bir bakış açısı ile kurum tiplerinin müdür yardımcıları için farklılık oluşturmadığını ancak müdürler için mutlaka uygulanması gerektiğine vurgu yapmıştır.

Milli Eğitimi Bakanlığı tarafından yönetici atama ve yer değiştirme sürecine ilişkin geçmişten günümüze 7 yönetmelik ve birçok genelge yayınlanmış olmasına rağmen halen yönetmeliğin içeriği ve uygulanışına ilişskin tartışmalar mevcuttur. Hızlı bir değişim ve dönüşüm yaşanan dünyaya ayak uydurabilmek için son yıllarda Milli Eğitim Bakanlığ 1 tarafından, eğitim ve öğretim faaliyetlerinin doğrudan ve dolaylı olarak ilgilendiren değişiklikler ve yenilikler yapılmaktadır. Ancak yönetici atama ve yer değiştirme süreci gibi yakın geçmişimizde uygulamaya konulan Sözleşmeli Öğretmenlik, Öğretmen Kariyer Basamaklarında Yükselme, 4+4+4 eğitim sistemi v.b. gibi yeni uygulamalar beraberinde birçok tartışmaya yol açmıştır. Bu noktadan hareketle bakanlık yetkililerinin eğitim ve öğretim faaliyetlerini doğrudan veya dolaylı olarak etkileyebilmek uygulamaları başlatmadan önce konunun tüm ilgili tarafindan 
tartışılmasına imkân tanıması ve yeni uygulamalarla ilgili geniş kapsamlı mutabakat sağlanması ileride doğabilecek sorunların önceden önlenmesi noktasında önem arz etmektedir. Aksi takdirde yeni uygulamaların bazı sorunları çözerken, yeni sorunları da beraberinde getireceği unutulmaması gereken önemli bir gerçektir (Demir ve Pınar, 2013).

Araştırma bulguları kapsamında:

1. Sözlü sınavı yapacak olan komisyonun çeşitli baskılara maruz kalarak doğru ve adil karar verme yeteneğinin oluşmayacağından dolayı sözlü sınavın yönetici atamalarında bir ölçüt olarak kullanılmaması,

2. Valiliklerin siyasi baskı altında kalacağı ve valiliğin yöneticileri yeterince tanıma firsatı bulamayacağından dolayı valiliklerin yönetici atama sisteminde olmaması

3. Sözlü sınav yerine yönetici atama yönetmeliğinde yer alan ve yöneticilerin göstermiş oldukları performansa yönelik olarak verilen ödüllerin ve eğitimle ilgili yapılan lisansüstü çalışmaların yönetici atamadaki ağırlıklarının arttırılması,

4. Beş y1l öğretmenlik yapanların sınavla doğrudan okul müdürü olmalarını sağlayan maddenin kaldırılması ve müdür olma koşulları arasına belli bir süre müdür yardımcısı olarak görev yapma şartının getirilmesi,

5. Sendika temsilcilerinin il değerlendirme kurulunda bulunmaları,

6. Katılımcıların kurum tiplerinin tek tip kuruma dönüştürülmesi konusunda farklı görüşler beyan etmelerinden dolayı bu konunun tekrar tartışmaya açılması ve değerlendirilmesi,

7. Zorunlu rotasyon için öngörülen kurumda çalışma süresinin son yönetmelikte öngörüldüğü gibi 8 yıl değil bir önceki yönetmelikte öngörüldüğü gibi 5 yıl olarak düzenlenmesi önerilebilir.

\section{Kaynakça}

Akyüz, S. (2007). Türk ve İngiliz örgün ĕgitim sistemlerinde ĕgitim yöneticilerini yetiştirme, atama ve politika uygulamalarının karşıllaştırılması. (Yayınlanmamış yüksek lisans tezi). Yeditepe Üniversitesi Sosyal Bilimler Enstitüsü, İstanbul.

Arıkan, G. (2007). Milli Ë̆itim Bakanlı̆̆ı'nın okul yöneticilerini atama sürecinde izlediği politikaların ve uygulamaların incelenmesi. (Yayınlanmamış yüksek lisans tezi). Beykent Üniversitesi Sosyal Bilimler Enstitüsü, İstanbul.

Aslanargun, E. (2011). Türkiye'de okul yönetimi ve atama yönetmelikleri, NWSA, eJournal of New World Sciences Academy Education Sciences, 6(4), 2646-2659.

Babaoğlan, E. (2007). İlköğretim okulu yöneticilerinde tükenmişliğin bazı değişkenlere göre araştırılması. Mehmet Akif Ersoy Üniversitesi Eğitim Fakültesi Dergisi, (14), 55-67.

Bakioğlu, A. \& Özcan, K. (2001). İlköğretim okul yöneticilerinin kariyer gelişimleri. Kuram ve Uygulamada Ĕ̈itim Bilimleri, 1, 39-57. 
Cemaloğlu, N. (2005). Türkiye'de okul yöneticisi yetiştirme ve istihdamı: Var olan durum, gelecekteki olası gelişmeler ve sorunlar. G. ̈. Gazi Eğitim Fakültesi Dergisi, 25(2), 249-274.

Çepni, S. (2001). Araştırmacı öğretmen ve öğrenciler için: Araştırma ve proje çalışmalarına giriş. Trabzon: Erol Ofset.

Demir, S.B. \& Pınar, M.A. (2013). 2011 Y1lı Yönetici Atama ve Yer Değiştirme Yönetmeği’nin İçeriğine Ve Puanlama Ölçütlerine İlişkin Yönetici Görüşlerinin İncelenmesi. Turkish Studies, 8(6), 123-143.

Dönmez, B. ve Güneş, H. (2001). İlköğretim okulu yöneticilerinde tükenmişlik. Ĕ̈itim Araştırmaları, 5, 71-78.

Ekiz, D. (2003). Eğitimde Araştırma Yöntem ve Metodlarına Giriş. Ankara: Anı Yayıncilik.

Graczyk, S. L. (1991). A model for planning graduate programs in school business administration. Planning and Changing, 22(2), 108-120.

Günay, E. (2004). Ĕğitim kurumlarına yönetici seçme, yetiştirme ve atamaya ilişkin yönetici ve öğretmen görüşlerinin değerlendirilmesi (Ankara ili örneği). (Yayınlanmamış yüksek lisans tezi). Ankara Üniversitesi Eğitim Bilimleri Enstitüsü, Ankara.

Ishida, H. (1997). MBA education in Japan. The experience of management education at the graduate school of business administration, Keio University, Japan. Journal of Management Development, 16(3), 185-196.

Koçak, R. (2009). Okul yöneticilerinin mesleki tükenmişlik düzeylerinin bazı değişkenler açısından incelenmesi. Fırat Üniversitesi Sosyal Bilimler Dergisi, 19(1), 65-83.

Korkmaz, M. (2005). Okul yöneticilerinin yetiştirilmesi: sorunlar, çözümler ve öneriler. G.Ü. Gazi Eğitim Fakültesi Dergisi, 25 (3), 237-252.

Kurtulmuş, M., Günda, A. \& Ardıç, T. (2012). Zorunlu yer değişikliği uygulamasına (rotasyon) ilişkin ilköğretim yöneticilerinin görüşleri. Elektronik Eğitim Bilimleri Dergisi, 1(1), 49-57.

Marshall, C. \& Rossman, G. B. (1999). Designing qualitative research. London: Sage Publications.

MEB (2003). Millî Eğitim Bakanlığı yönetici Atama ve Görevde Yükselme Yönetmeliği. 11.06.2003 Tarih ve 25135 Sayılı Resmi Gazete.

MEB (2004). Milli Eğitim Bakanlığı Eğitim Kurumları Yöneticilerinin Atama ve Yer Değiştirme Yönetmeliği, 11.01.2004 Tarih ve 25343 Sayılı Resmi Gazete.

MEB (2006). Milli Eğitim Bakanlığı Eğitim Kurumları Yöneticilerinin Atama ve Yer Değiştirme Yönetmeliğinde Değişiklik Yapılmasına Dair Yönetmelik, 04.03.2006 Tarih ve 26098 Sayılı Resmi Gazete.

MEB (2007). Milli Eğitim Bakanlığı Eğitim Kurumları Yöneticilerinin Atama Yönetmeliği, 13.04.2007 Tarih ve 26492 Sayılı Resmi Gazete. 
MEB (2008). Milli Eğitim Bakanlığı Eğitim Kurumları Yöneticileri Yönetmeliği, 24.04.2008 Tarih ve 26856 Sayılı Resmi Gazete.

MEB (2009). Milli Eğitim Bakanlığı Eğitim Kurumları Yöneticilerinin Atama ve Yer Değiştirmelerine İlişkin Yönetmelik, 13.08.2009 Tarih ve 27318 Sayılı Resmi Gazete.

MEB (2011). Milli Eğitim Bakanlığı Eğitim Kurumları Yöneticilerinin Atama ve Yer Değiştirmelerine İlişkin Yönetmeliğinde Değişiklik Yapılmasına Dair Yönetmelik, 9 Ağustos 2011 tarihli Resmi Gazete.

MEB (2013). Millî Eğitim Bakanlığı Eğitim Kurumları Yöneticilerinin Atama ve Yer Değiştirmelerine İlişkin Yönetmelik, 28 Şubat 2013 Tarih Ve 28573 Sayılı Resmî Gazete.

Mills, G. E. (2003). Action research a guide for the teacher researcher. Boston: Pearson Education.

Miles, M. B. \& Huberman, A. M. (1994). Qualitative data analysis: An expanded sourcebook. London: Sage Publications.

Özmen, F. \& Kömürlü, F. (2010). Eğitim örgütlerine yönetici seçme ve atamada yaşanan sorunlar ve yönetici görüşleri temelinde çözüm önerileri. Sosyal ve Beşeri Bilimler Dergisi, 2(1), 25-32.

Özmen, F. \& Yörük, S. (2004). Sinavla atanan ilköğretim okulu yöneticilerinin öğretmenlerin mesleki gelişimindeki etkililik düzeyleri (Malatya ili örneği). XIII. Ulusal Eğitim Bilimleri Kurultayl, 6-9 Temmuz 2004, İnönü Üniversitesi, Eğitim Fakültesi, Malatya.

Patton, Q. M. (2002). Qualitative evaluation and research methods. London: Sage Publications.

Serin, S. (2007). Ilköğretim okulu yöneticilerinin yönetime ilişkin başarılarının sınıf ve branş öğretmenleri tarafindan değerlendirilmesi (Siirt ili örneği). (Yayınlanmamış yüksek lisans tezi). Beykent Üniversitesi Sosyal Bilimler Enstitüsü, İstanbul.

Silah, M. (2001). Eğitim örgütlerinde hizmetin niteliğini arttırmak için personelin ödüllendirilmesi. C. Ü. İktisadi ve İdari Bilimler Dergisi, 2(1), 95-109.

Silverman, D. (2005). Doing qualitative research: A practical handbook. London: Sage Publications.

Taş, A. \& Önder, E. (2010). 2004 yılı ve sonrasında yayınlanan eğitim kurumları yöneticilerinin atama ve yer değiştirmelerine ilişkin yönetmeliklerin karşılaştırması. Süleyman Demirel Üniversitesi Sosyal Bilimler Enstitüsü Dergisi, 2(12), 171-185.

Turan, S. \& Şişman, M. (2000). Okul yöneticileri için standartlar: eğitim yöneticilerinin bilgi temelleri üzerine düşünceler. Balıkesir Üniversitesi Sosyal Bilimler Enstitüsü Dergisi, 3(4), 68-87.

Tonbul, Y. \& Sağıroğlu, S. (2012). Okul müdürlerinin zorunlu yer değiştirme uygulamasına ilişkin bir araştırma. Kuram ve Uygulamada Eğitim Yönetimi [Educational Administration: Theory and Practice], 18(2), 313-339. 
Yeloğlu, D. (2008). Eğitim kurumlarına yönetici seçme ve atamaya ilişkin okul yöneticilerinin görüşlerinin değerlendirilmesi. (Yayınlanmamış yüksek lisans tezi). Yeditepe Üniversitesi Sosyal Bilimler Enstitüsü, İstanbul.

Yıldırım, A. \& Şimşek, H. (2011). Sosyal bilimlerde nitel araştırma yöntemleri. Ankara: Seçkin Yayıncılık. 